\title{
GCU
}

Glasgow Caledonian

University

University for the Common Good

\section{Social entrepreneurship research in the Greater China Region: a scoping review and new research framework}

\author{
Chandra, Yanto; Teasdale, Simon; Tjiptono, Fandy
}

Published in:

Journal of Asian Public Policy

DOI:

$10.1080 / 17516234.2020 .1802907$

Publication date:

2021

Document Version

Author accepted manuscript

Link to publication in ResearchOnline

Citation for published version (Harvard):

Chandra, Y, Teasdale, S \& Tjiptono, F 2021, 'Social entrepreneurship research in the Greater China Region: a scoping review and new research framework', Journal of Asian Public Policy, vol. 14, no. 2, pp. 152-181. https://doi.org/10.1080/17516234.2020.1802907

\section{General rights}

Copyright and moral rights for the publications made accessible in the public portal are retained by the authors and/or other copyright owners and it is a condition of accessing publications that users recognise and abide by the legal requirements associated with these rights.

Take down policy

If you believe that this document breaches copyright please view our takedown policy at https://edshare.gcu.ac.uk/id/eprint/5179 for details of how to contact us. 
Social Entrepreneurship Research in the Greater China Region: A Scoping Review and New Research Framework

\author{
Yanto CHANDRA * \\ Department of Applied Social Sciences \& \\ Centre for Social Policy and Social Entrepreneurship \\ The Hong Kong Polytechnic University \\ Hung Hom, Kowloon, \\ Hong Kong SAR \\ Tel: (852) 34003675 \\ Email: yanto.chandra@polyu.edu.hk
}

Simon TEASDALE

Glasgow School for Business and Society

Glasgow Caledonian University, Glasgow, United Kingdom

Tel: +441413318627

simon.teasdale@gcu.ac.uk

Fandy Tjiptono

School of Marketing and International Business, Victoria University of Wellington, New Zealand

Email: fandy.tjiptono@vuw.ac.nz

*corresponding author

Running head: Social Entrepreneurship in the Greater China Region

Keywords: social entrepreneurship, review, China, Chinese, Hong Kong, Taiwan

This is the author accepted version of a paper to be published in Journal of Asian Public

Policy 


\begin{abstract}
Increasing attention is being paid to the practice of social entrepreneurship in China, Hong Kong and Taiwan, or so-called the Greater China Region. Despite the growing popularity of SE as a field of inquiry in the Region, there has been no attempt to appraise the state of the art of the intellectual development of SE scholarship in the Region. In this article, we conducted a scoping review and critically analyzed 46 peer-reviewed articles published on SE in the Greater China that were sourced from Web of Science and Google Scholar. Overall, we found that the Chinese SE scholarship lacks novelty, focuses on what is already "obvious" to the mainstream SE scholarship, and follows the similar "style and taste” of SE research in the West. As a remedy, we propose a new framework for Chinese SE research by broadening the scope of SE, localizing theoretical lenses and concepts, exploring new contexts, and re-tooling and reskilling. We call upon SE scholars to pursue more out-of-the-box, original, and daring research to contribute to and engage in meaningful conversation with the mainstream SE scholarship.
\end{abstract}




\section{INTRODUCTION}

Social entrepreneurship (SE) has been touted as an alternative solution to various socialenvironmental problems that the state, for-profit and non-profit sector cannot (or will not) address "efficiently" (Salamon, 1987). Although SE has flourished for several decades in Western countries, it is a relatively nascent phenomenon in the Greater China Region - China, Hong Kong and Taiwan - a region that has a shared cultural, linguistic and historical heritage (Chandra \& Wong, 2016; Zhao, 2012; Yu, 2013). To be brief, we call the SE phenomenon in this Region as "Greater China Social Entrepreneurship". Examples include the Shanghai Young Bakers, a social enterprise that offers bakery training and employment opportunities for marginalized youths in China; Agent of Change, which provides low-cost daily necessities for the low-income families in Hong Kong; and Duofu that provides barrier free transportation for the disabled in Taiwan.

The SE concept made its first appearance in China in 2004 during international conferences held in China (Lane, 2012). SE as practice stems from the establishment of Canyou Group, a software company that mostly employs people with disability as programmers, in 1997 in Shenzhen (Gu, 2012). In Hong Kong, SE first appeared in the Commission of Poverty (CoP) meetings in 2005 and in a local SE conference hosted by CoP and Central Policy Unit (CPU) in 2006 (Chan \& Yuen, 2013) - as part of the government response to the Asian financial crisis (Tang et al., 2008). The antecedents of SE in Hong Kong include Home Safety Association (SCHSA) that began in

\footnotetext{
${ }^{1}$ The term 'Greater China Region has been used widely across various disciplines. To-date, there is no unified definition on 'Greater China.' In this paper, we use the term 'Greater China' to refer to geographical contexts that share cultural and linguistic affinities, as is the case with China, Hong Kong and Taiwan. Moreover, there is a myriad number of publications whose authorships is a joint work of scholars across Mainland China, Macau, Hong Kong, and Taiwan and therefore it is akin to big cluster of scholars and publications worthy of investigation on its own. The Greater China region also includes Macao but since our article found no papers specifically on Macao, we henceforth refer only to China, Hong Kong and Taiwan.
} 
1996, as a fee paying elderly emergency services, and the Enhancing Employment of People with Disabilities through Small Enterprise Project in 2001 by Hong Kong's Social Work Department. The former never labelled itself as SE until many years later while the latter was only known as 'workfare' rather than 'social enterprise or social entrepreneurship' policy until recent years (Kee, 2016). In Taiwan, SE first appeared in the 1990s when a number of non-profit organizations, such as Children Are Us and Sunshine Social Welfare Foundations, established business units in the form of bakery and car wash centers, respectively (Kuan \& Wang, 2015). Today, the SE sector is a legitimate sector at the intersection between public, market and nonprofit sectors (Chandra \& Wong, 2016), with the number ${ }^{\underline{2}}$ of social enterprises totaling more than 1,500 in China (CSESC, 2020), 651 in Hong Kong (SEBC, 2018), and 450 in Taiwan (Social Enterprise Insights Asia, 2020) as of May 2020.

Although research on Greater China $\mathrm{SE}^{3}$ is flourishing (e.g., Chan et al., 2011; Chan \& Yuen, 2013; Defourny \& Kim, 2011; Ho \& Chan, 2010; Kuan et al., 2011; Poon et al., 2009; Zhao \& Han, 2019), there has been little efforts to take stock of the development of SE as a field of research. A review of the development of SE scholarship is important because, first, it allows us to look at the history of the progression and contribution of intellectual ideas in the field, and second, it can spark a new conversation and debates among scholars which can lead to the proliferation of new research that pushes the scholarship forward.

\footnotetext{
${ }^{2}$ The number of social enterprises in China and Hong Kong was quoted from well-known databases of SE in each site, while the number in Taiwan was quoted from a semi-official website that monitors the SE development in Taiwan. All

${ }^{3}$ We define Greater China SE research as research that identifies itself as in the area or topic of SE - using data, context, theoretical perspectives - regardless of the country of origin of the authors.
} 
While several review articles of SE research exist - among the most prominent ones are the work of Short et al (2009), Doherty et al (2014), Saebi et al (2019), and Gupta et al (2020) - none have focused on the Greater China Region. Most SE review articles tend to focus on the overall body of SE scholarship, which is dominated by articles published by prominent US and European academics, usually (but not exclusively) focusing on SE in these countries. Accordingly, they lead towards a rather 'Westernized' overview of theoretical lenses and methodological approaches, and identify fairly homogenous future research agendas. Our preliminary understanding of Greater China SE scholarship suggested that scholars may have too slavishly adopted the "style and taste" of SE research in the West, in particular in how SE research is framed and defined, and the theoretical lenses used in SE research. Hence there appears to be a lack of new discoveries and novel research programmes on SE emanating from this region. To test whether these impressions are accurate, we asked the following research question: What is the state of the art of social entrepreneurship research in the Greater China Region (China, Hong Kong, and Taiwan)? We sought to answer this question by conducting a scoping review of peer-reviewed articles published on SE in this Region, revisiting cognate literature, and reflecting on what they mean to drive future research agendas in the field.

The article proceeds as follows. In the next section, we describe the methodology used in the scoping review. This led us to a corpus of 46 articles on Greater China SE scholarship. In our findings section we first summarize the plurality of the definition of SE, paying particular attention to how it has been defined in the Greater China Region. Next, we highlight influential theories that have gone mainstream in the SE literature, mostly developed from the West, and the theories commonly used in SE research in the Region. We also review the types of methodology 
employed by Greater China SE scholars. Finally, we critically reflect on our findings and propose new research frameworks that local and international scholars can pursue.

\section{METHODOLOGY}

There are many types of reviews that scholars have used to offer an understanding about the intellectual progression of a field of research (see Grant \& Booth, 2009). Among the most popular ones are meta-analysis, systematic review, scientometric/bibliometric and scoping review. In this study, we chose scoping review because it is ideal to identify and map the available evidence and to determine the scope or coverage of a body of literature on a given topic (Arksey \& O'Malley, 2005; Dickson-Woods et al., 2006; Munn et al., 2018). Scoping review serves the following purposes (Munn et al., 2018): to identify the key concepts or definitions in the literature, to examine how research is conducted on a certain topic or field, to identify key characteristics related to a concept, and to identify knowledge gaps.

Our scoping review focused on peer-reviewed SE journal articles where Greater China is the geographic focus. Country of origin of the authors is not seen as relevant to selection criteria. This is important because there are non-Chinese/Hong Kongese/Taiwanese authors who publish their work in this space.

The systematic and extensive search ${ }^{4}$ was conducted between 1 January 2020 and 6 May 2020 in Web of Science (WoS) using these keywords ${ }^{\underline{5}}$ "social entrepreneurship” OR “social enterprise”

\footnotetext{
${ }^{4}$ The time scope for the search was not constrained to any particular years in order to ensure as wide a coverage of publications as possible.

${ }^{5}$ These keywords were used based on a preliminary assessment that Corporate social responsibility (CSR) was excluded from this study because it belongs to a different literature stream.
} 
OR “social venture” OR “social business” OR “socially responsible business” AND “China” OR "Chinese"; and then_we repeated the same key word search by focusing on "Hong Kong” OR "Hongkong” $\underline{6}$ and we repeated the same key word search on "Taiwan” OR "Taiwanese" and finally on "Macau" ${ }^{7}$ or "Macao". These procedures were conducted separately for each geographical site. Finally, the same keywords were used to search for publications in Google Scholar to ensure a wide coverage that may not have been covered by WoS. The focus of our review was "peer reviewed journal articles” because they are "certified knowledge” (RamosRodríguez and Ruíz-Navarro 2004).

The sample breakdown of the articles reviewed is as follows (see Appendix). Using the search procedures above, 130 articles were retrieved from Web of Science (WoS) and 102 articles were retrieved from Google Scholar. We merged the articles and cross-checked them for duplicates, and this led to 138 articles screened for retrieval. Next, we excluded 1) articles published in unknown, predatory journals [e.g., Makara Human Behavior Studies in Asia, Convivium, etc.], 2) articles whose topics were outside of China, Hong Kong, or Taiwan [e.g., Lodhia et al (2017) that examined e-waste handling in Australia, or Elkington (2006) that discussed sustainability governance broadly and not situating it in China/Hong Kong/Taiwan), 3) articles that used the term "social entrepreneurship" loosely but apparently were not relevant to this study (e.g., Tucker et al (2014) that examined the role of nonprofits in HIV/AIDS testing in China but used the term "SE" as a buzzword, or Lee et al (2018) that studied vocational training for psychiatric patients which is an article on rehabilitation than SE), and 4) articles accidentally captured but

\footnotetext{
${ }^{6}$ We conducted search using "Hong Kong" and "Hongkong” because authors and journals have used both terms. Therefore, this ensured that the search had casted a wide net.

7 The key word search on "Macau" and "Macao" in WoS and Google Scholar yielded nil results. Hence, this article on reviews the publications from China, Hong Kong, and Taiwan.
} 
were apparently conference papers (e.g., conference on logistics and informatics, or education). The final exclusion after in-depth reading resulted in 46 articles included in this review comprising 25 from China, 8 from Hong Kong, and 13 from Taiwan, which we will discuss next. Because the sample produced was relatively small, we used an interpretivist approach (DixonWoods et al., 2006; Jones et al., 2011) to make sense of the articles reviewed.

As a part of an 'interpretivist' tradition in scoping review, we took a critical view of the body of literature examined and acknowledged the authorial voice that is grounded in evidence (DixonWoods et al., 2006). The interpretive investigation of the published materials started with the first author conducting the first round of review using an excel sheet (see the Corpus Data file), and then another author replicated the search process in WoS and Google Scholar and followed by three rounds of discussions between these authors to 'reach consensus' on the review (e.g., on research questions, theories used, findings). Finally, another author reviewed the review and the corpus data as a whole and provided suggestions to further refine the meaning and articulations of the review.

\section{FINDINGS}

\subsection{Descriptive Analysis}

Of the 46 articles included in the scoping review, 43 (93.4\%) were empirical articles, and only three (6.5\%) were conceptual articles (see Table 1).

Most of the articles (80.4\%) focused on either China, Hong Kong, or Taiwan as the geographic context. There were seven papers (15.2\%) that studied more than one geographic context such as 
comparing China versus USA (e.g., Yang et al., 2015), China versus Hong Kong versus Taiwan (e.g., Luo \& Huang, 2019), Hong Kong and Taiwan (e.g., Chan et al., 2011; Ip et al., 2019; Kwan et al., 2011; Hsu \& Wang, 2019), Taiwan versus South Korea (e.g., Yang et al., 2018).

The disciplinary origins of the reviewed articles range from management, organization and entrepreneurship (26 or 56.5\%), nonprofit (6 or 13\%), social work (5 or $10.8 \%$ ), public policy (3 or $6.5 \%$ ), economics (2 or $4.3 \%$ ) and tourism (2 of $4.3 \%$ ).

\subsection{Definitions of Social Entrepreneurship}

Definitions are important because they influence the scope and generalization of a phenomenon being studied. Social entrepreneurship (SE) has been defined in a variety of ways (see the upper part of Table 1). As Table 1 shows, SE is an area of research interest of various disciplines and has diverse meanings, some of which are overlapping. The most commonly used definition has been the one used by business management research where SE is defined as 1) organizing approach and organizations that combine social welfare and commercial logics or hybrid organization ('SE as management and organization phenomenon’, Battilana \& Dorado, 2010; Short et al., 2009). Four other major definitions focus on SE as 2) nonprofits or social work embracing business practices ('SE as a welfare phenomenon’, Eikenberry \& Kluver, 2004; Grey et al., 2013), 3) alternative development model ('SE as a development phenomenon', Venot, 2016), 4) citizen driven participatory governance as an extension of the government arm ('SE as a governance phenomenon’, Defourny \& Nyssens 2012; Jung et al., 2016) and 5) a tool intended for social change ('SE as a political phenomenon', Ganz et al., 2018). 
Overall, as Table 1 reveals, SE has been viewed as predominantly an organizational phenomenon (or studied from a management and organization lens) and a new form of practice that combines multiple ways and logics of doing things to solve complex problems.

\section{----- Table 1 goes about here -----}

In defining SE, the Greater China SE scholarship has been dominated by papers from the management and related disciplines such as organization and entrepreneurship (e.g., Chandra, 2017a; Yiu et al., 2014; Zhao \& Han, 2019). The SE field has also attracted non-business scholars, as shown by papers from the nonprofit, social work, public policy, economics, and tourism disciplines. This may reflect the interdisciplinary of SE as a field of research, and or its hybrid (combining business and nonprofit approaches) and often-ambiguous nature (Yang, 2016), SE can be examined from privateness, nonprofitness, and publicness aspects, as well as economic and sustainability phenomenon.

As Table 1 shows, the Greater China SE scholarship has a very high consistency with the five well-accepted definitions in the mainstream SE scholarship described above (see the lower part of Table 1). To put it differently, there has been limited definitional breakthrough that came out of the Greater China SE scholarship. A few SE definitions that are relatively new to the world emanating from this Region include danwei, a social resource distributor as a form of SE (Curtis, 2011) — from the political economy discipline-and collective enterprise ownership in the rural areas (Lan et al., 2014; Poon et al., 2009)—from the management/development work discipline-as well as sustainability with social-commercial-ecological value creation (Wang et al., 2016; 
Zeng, 2018)—which are contextualized within the transitioning socialist market (hybrid) economy in China.

What differentiates the Region from others is the bigger role of the state and its policies that legitimizes $\mathrm{SE}$ as a new way and form of organizing to tackle complex societal problem (e.g., Chandra \& Wong, 2016). Even in the democratic region of Taiwan, with the so-called strong grassroots movements, state policies on SE and social innovation (SE Insights Asia, 2020) play very important roles in driving the growth of SE sector and scholarship. In some ways, the rising popularity of Creating Shared Value (CSV) movement (Porter \& Kramer, 2011) in the Region — such as Nestle CSV model in fresh milk sourcing in China's Heilongjiang, Shandong, and Inner Mongolio (Nestle, 2013) and publicly-listed Pura Pharmaceutical from Hong Kong that works with poor farmers in China's Guizhou to produce high quality medicinal herbs—is offering opportunities for large corporations to re-brand and re-label their corporate social responsibility (CSR) into SE initiatives. Overall, these imply that there could be alternative ways to define SE, as a form of public sector innovation or entrepreneurship (Bartlett \& Dibben, 2002; Mintrom \& \& Norman, 2009), as well as a form of corporate social entrepreneurship (Austin \& Reffico, 2009).

\subsection{Research Questions}

Our review shows that the Greater China SE scholars have focused on nine types of research question when investigating SE research (see Table 2). They comprise those that studied the antecedents (e.g., what drives success in SE; determinants of SE intention), SE emergence and development process (e.g., motivations to pursue SE; SE formation process), outcomes (e.g., 
performance and social impact of SE; impact of SE on poor areas), history (e.g., how an SE evolves over time), boundary condition testing (e.g., testing direct and indirect effects of certain variables such as human resources practices or creativity), problems and challenges facing SE (e.g., dilemmas in operating SE), managing tensions (e.g., how SEs balance social and economic goals), comparative studies (e.g., similarities and differences in the ways of governance of SEs), and characteristics of SE (e.g., the nature and meaning of work in SE; the role of family in SE).

\section{----- Table 2 goes about here -----}

The top five most popular research questions asked, in consecutive order, pertain to $S E$ characteristics (12 or 26\%), SE emergence and development process (11 or 23.9\%), problems and challenges (3 or 6.5\%), outcomes (7 or 15.2\%), and antecedents (5 or 10.8\%) (see Appendix for more details on the breakdown). These three questions are basically "descriptive" in nature and account for $56.5 \%$ of published articles. This suggests that Greater China SE research is dominated by descriptive research. Note however, that those investigating the antecedents, outcomes, and doing comparative studies were predominantly exploratory studies in nature. Altogether, these indicate that a substantial number of publications from this Region can be characterized as still at the pre-paradigmatic stage (i.e., focusing on SE emergence, defining and articulating their characteristics, the problems faced by SEs) (see Nicholls, 2010), similar to the early years of SE research in the West (e.g., Dees, 1998; Dees \& Elias, 1998; Leadbetter, 1997; Mair \& Marti, 2006; Martin \& Osberg, 2007). There is a serious lack of research that asks "to what extent” type of question, teasing causality, or developing novel theory or testing theory imported from other fields to extend and enrich SE scholarship. 
We did not provide a comparison with the research questions asked in the mainstream SE scholarship, but what we can infer from Table 2 is that the research questions asked in the Chinese SE scholarship are not well differentiated from the mainstream SE research.

\subsection{Theoretical Lenses}

We also conducted analysis of the theoretical lenses used in SE research. The mainstream SE scholarship has used approximately nine major theoretical lenses, which are: 1) institutional theory, 2) empowerment theory, 3) compassion/ pro-social, 4) resource-based view, 5) meaningful work, 6) narrative/rhetoric theory, 7) effectuation theory, 8) bricolage theory, and 9) identity theory (see the upper half of the Table 3 for more details).

\section{----- Table 3 goes about here -----}

As can be seen at the bottom half of Table 3, Greater China SE scholarship has used similar theoretical lenses used by mainstream SE researchers. These span the use of sociological (e.g., institutional, structuration, identity), psychological (e.g., moral sentiments, self-determination, planned behavior), economics (e.g., economics, development), management and organizational behavior (e.g., governance, paradox, cooperative, value co-creation, organizational ecology), and social work (e.g., empowerment) theories.

Articles from Hong Kong tend to focus on three theories, which are empowerment theory (e.g., Chui et al., 2019), institutional theory (e.g., Chandra, 2017a), and governance theory (e.g., Leung 
et al., 2019), and tend to focus on work-integration social enterprise (WISE) as a strategic research site (Merton, 1987). In contrast, articles from China employed a much more diverse theoretical sources, from paradox theory (Zheng et al., 2020), theory of moral sentiments (Yiu et al., 2014), self-determination theory (Zhang et al., 2018), Danwei (Curtis, 2011) to cooperative theory (Lan et al., 2014), among others. Articles from Taiwan tend to use management (Hsieh et al., 2018) and non-profit (Kao \& Huang, 2015) theories. We argue that these specializations are likely due to the disciplinary expertise of the scholars publishing SE research (e.g., prior knowledge determines the research opportunities of the scholars). For instance, the Taiwanese scholars were primarily from business schools and to some extent social work schools, while those in Hong Kong tend to come from management, social work and public administration fields, while those in China come from a wider range of disciplinary expertise.

One of the unique theoretical lenses worth highlighting here was the use of Danwei theory by Curtis (2011). Danwei is a form of social security that is common in socialist economy like China in which the neighborhood provides all types of social security (e.g., education, employment, health care, and retirement care) to residents. Curtis identified three types of danwei: qiye danwei ('profit-oriented' or production-related units), shiye danwei (non-profit or non-production units), and xingzheng danwei (administrative units). However, none of the other articles reviewed had used local or native theories or concepts that are unique to the Region but can offer new revelation and novel contribution to the SE field. This is a little unfortunate given that SE is a contextualized phenomenon spatially, temporally, historically, linguistically, and institutionally (Welter, 2011; Welter et al., 2019). 


\subsection{Methodological apparatus}

We also reviewed the methodologies used in the reviewed articles. As shown in Table 4, more than half of the articles used case study research as the main methodology. The typical usage of the case study was to illustrate cases or phenomenon but not for the purpose of theory development work (Gehman et al., 2018; Shepherd \& Suddaby, 2017) such as discovering new concepts, new processes, or identifying new phenomena. This finding aligns with our earlier summation of Chinese SE scholarship being at the pre-paradigmatic stage and partly explains why there are limited theoretical breakthroughs emanating from Chinese SE scholarship.

----- Table 4 goes about here -----

Only 12 (or 26\%) articles used survey methodology (i.e., Yang et al., 2015; Yu et al., 2014; Ge et al., 2019; Zhang et al., 2018; Liu et al., 2020; Wang \& Zhou, 2020; Chan et al., 2011; Leung et al., 2019; Ip et al., 2018; Hsu \& Wang, 2019; Yu \& Wang, 2019; Chen, 2011). Some articles used relatively novel methodologies such as corpus linguistics (Chandra, 2017a) and ethnographic case study (Dai et al., 2017).

None of the articles used more sophisticated methodological apparatus such as (lab/field/choice) experiments (c.f. Smith et al., 2012) to tease out causality, advanced computational social sciences and social network analysis (Imbert et al., 2019), to creative forms of doing qualitative research such as using netnography (Kozinets, 2002). However, this problem is not inherent to Greater China SE scholarship but also applies to the mainstream SE scholarship. Obviously, 
there are still plenty of opportunities for scholars to retool and apply more advanced and powerful methodologies.

The contexts of the articles reviewed were diverse and include rural villages (Poon et al. 2009), nursing homes organized by religious institutions (Zhang, 2015), post-disaster (Yu, 2016), sustainability (Wang et al., 2016), microfinance (Zhao \& Han, 2019), elderly care homes (Wong \& Tang, 2006), SE certification (Lou \& Huang, 2019), work-integration social enterprises (Chui et al., 2019; Leung et al., 2019). These diverse contexts reflect the diversity of those studied in the mainstream SE literature.

\section{TOWARDS A NEW FRAMEWORK FOR CHINESE SE SCHOLARSHIP}

Based on the foregoing analyses, we propose a framework that can be used by scholars to push the Greater China SE scholarship forward. While these are not comprehensive, they offer initial ideas to spark conversations and debate among scholars in the field. We propose broadening the scope, localizing, re-contextualizing, and retooling to push the Greater China SE scholarship forward.

\subsection{Broadening the Scope}

\subsubsection{Social and Systemic Change}

Most of the articles reviewed above have focused on SE as a micro- and meso-level phenomenon (Van Wijk et al., 2019). That is, they focus on questions about the individuals (e.g., their intentions, motivations, resources) and what happen inside the social enterprises (e.g., the tensions, value creation, identity management, adoption of new behavior). None of the articles 
reviewed sought to study SE as a broader system change efforts, or macro level change. Recent research in the mainstream SE scholarship has alluded to this such as the work of Ganz et al (2018) that made us ponder the question "social enterprise is not social change”. They argued that "solving systemic social problems takes people, politics, and power” (p. 59).

We do not suggest that SE researchers should embrace the kind of research that political scientists have done for decades such as studying political upheaval, regime change, or ideologically motivated social movements. Rather, there are plenty of avenues to study SE as $a$ positive social movement, as an interaction between micro to macro (institutional) level forces to tackle many of the wicked public problems, from climate change, poverty, and natural disasters, in collaboration with the government and businesses, and the welfare sector. It is well-known that the state and big businesses are a catalyst and driver of social and systemic change in the Region. For instance, the Hongkong Government and the Social Innovation and Entrepreneurship Fund (SIFUND) are key actors in driving the emergence of the SE sector in Hong Kong (Chan et al., 2019). This opens new avenues to study SE as a social movement, as a policy innovation or entrepreneurship (Bartlett \& Dibben, 2002; Mintrom \& \& Norman, 2009), as well as how corporations embrace SE at the core of their operations rather than as an add-on activity, or corporate social entrepreneurship (Austin \& Reffico, 2009).

Another exciting development is the role of certifications such as the fast-growing certified BCorp movement in the Region, and various forms of SE certifications such as Star of Social Innovation certification in China (SIRF, 2020), Hong Kong Social Enterprise Endorsement (SEE) Mark, and a similar initiative by Taiwan NPO Self-Regulation Alliance. The role, process, 
and impact of SE competitions held by many universities and SE hub organizations on individual, organizational and institutional levels were also largely missing in the reviewed articles. There are almost no articles in the review (except Luo \& Huang, 2019) that sought to study these areas. These represent institutional change making efforts that will open up new avenues for important research agendas. In other words, the systemic view of SE will bring closer other research that embraces an ecosystem approach of SE (c.f. Hazenberg et al., 2016) or broader macro level forces (Van Wijk et al., 2019), which will prove fruitful in pushing SE scholarship forward.

\subsubsection{Public Behavioral Change}

Existing Greater China SE scholarship tends to define or frame SE as a hybrid organizational phenomenon (Doherty et al., 2014; Battilana \& Lee, 2014). Importantly, the majority of the studies tend to focus on change at the organizational level (e.g., social and market performance) and to a smaller extent at the beneficiary level (e.g., meaning of work, social capital building, rehabilitation). It also reveals that Greater China SE scholars have a high appetite to study SE as "work-integration SE" phenomenon, perhaps the largest form of SE in the sector.

There is a void on research that examines $S E$ as tool to enact public behavioral change (c.f., Chandra \& Paras, 2020; Teasdale \& Dey, 2019; Moore, 1995). In fact, a key role of SE in the society is to change public perception and behavior towards desirable outcomes because norms, traditions and culture held by the public often constrain certain groups of individuals from being liberated from stigmatization, marginalization and exclusion. This is why a renegotiation, rearrangement and repositioning of roots of public problems including the public themselves is 
important for SE. For instance, many social enterprises in the Region employ people with disabilities or other marginalized groups. Most research on these SEs focuses on their role in job creation and empowerment. However, a big part of what they do is to change public attitudes and behavior to accept the disabled and disadvantaged groups in the society and workplaces. By reframing SE in the context of public behavioral change, scholars can ask new questions and bring in new theoretical perspectives thus advancing the SE scholarship. This requires behavioral science type approaches to experimentally study how public behavior can be stimulated or changed by the interventions performed by SEs (which will be further discussed in Section 4.4.).

Research along this line can also be cross-fertilized with the field of social marketing (Andreasen, 2002; Lee \& Kotler, 2019). Social marketing research (e.g., Almestahiri et al., 2017; Firestone et al., 2017) has studied how different kinds of strategies and interventions can be employed to stimulate a change in public behavior from tackling health (e.g., encouraging the use of condoms among vulnerable communities) and consumption (e.g., reducing tobacco consumption, obesity), to family planning (e.g., encouraging families to have children) problems. Many social enterprises in the Region aim to tackle health, environmental, urban, and discrimination issues are in the business of changing public behavior. This is an exciting new field of research for Greater China SE.

\subsubsection{Pluralistic organizing and organizations}

The practice of organizing and organizations in the Region usually transcends beyond simply doing one thing_or pursuing singular goal (e.g., making money or serving the society). Many Chinese/Hong Kongese/Taiwanese organizations have "complex" character in which the 
boundary between the privateness-nonprofitness-publicness (Chandra \& Paras, 2020) are often not clear-cut, and have pluralistic goals. "Pluralistic" refers to combining multiple elements or purposes such as doing good for the suffering others, practicing faiths or beliefs for higher goals, preserving certain traditions/culture and non-pecuniary others while making profits - all simultaneously within a single organization. As explained in the foregoing, there are nonobvious SE phenomena that had taken place for hundreds of years, at least, in this Region but they have not been labelled or identified as such by the locals. Arguably, SE is a linguistic innovation from the West; hence, the lack of its identification in the Region does not necessarily mean its absence.

For example, there are millions of — but not all — small family businesses that provide jobs to school drop outs, poor neighbors, and uneducated individuals, sell goods to the poor or needy on longer credit terms (to help with the poor's cash flow problems), provide soft loans for others' children education, and other forms of welfare support to (non) relatives and people with similar ethnic or village backgrounds in the Region (e.g., Chandra \& Shang, 2019). These practices are not common in the West and reflect the Greater China cultural context which is often 'missing' in the analysis sections of the articles we reviewed.

One typical example is the case of "Ming Gor", founder of Pei-Ho Barbecue Restaurant, located in the Sham Shui Po, the poorest district in Hong Kong, that provides very low cost meals as well as free lunchboxes to the homeless and poor elderly (HKFP, 2018; The Standard, 2019). From a quick glance, Pei-Ho restaurant looks like any ordinary eatery place, and the founder never calls themselves "social enterprises". Analyzing such small family businesses as "hybrid 
organizations” (Doherty et al., 2014; Battilana \& Lee, 2014) can show how these practices resemble the concept of social investment (Agrawal \& Hockerts, 2019; Nicholls \& Teasdale, 2019) but performed in an informal way. Pei-Ho Restaurant is a nice example of small enterprise that is a pluralistic organization - in that it exists to pursue a variety of different goals at the same time. As argued by Chandra and Shang (2019), the culture in the Region is characterized by informality and informal institutions rather than formal reporting and declaring activities in black and white.

We argue that concepts such as CSR and SE arose in the West as a response to the West's disenchantment for organizations that have traditionally focused on a singular purpose: businesses focus on making profit, nonprofits offering care voluntarily, and the government providing public services funded through taxation. In other words, in the West CSR and SE seek to push singular purpose organizations towards hybrid and even pluralistic purpose structures in order that they can develop new (or integrated) solutions to wicked problems that the singular purpose organizations have proved unable to tackle. However, in China, Hong Kong and Taiwan, organizations are more likely to already have multiple purposes and therefore hybridization or pluralization are unnecessary. Such "hidden or latent SE" is theoretically interesting and can spark paradoxes, creative tensions, and counter-intuitive ideas that, from a philosophy of science point of view, can lead to new breakthroughs or even paradigm shift.

As of yet few scholars have sort to conceptualize these pluralistic organizations as a peculiarly form of SE in Greater China. We argue that many interesting and important Greater China SE phenomena have gone unnoticed by scholars due to their rigid adherence to Western lenses. The 
literature of pluralistic organizations (Denis et al., 2011) is a good starting point for broadening the Greater China SE scholarship.

\subsection{Localizing Through Indigenous Theoretical Lenses and Concepts}

\subsubsection{Danwei}

The foregoing review reveals little exploration and exploitation of indigenous theoretical lenses and concepts from the Region. This is a little unfortunate because there is a well spring of theories, constructs and concepts available to push the SE scholarship. One of the interesting concepts that came out of this scoping review is Danwei (Curtis, 2011) and its embeddedness within the market socialism values and institutions. More can be done to understand the concepts like Danwei and others, how they work, and how they complement or compete with China's social welfare institutions. As China progressively espouses market values and combines it with its socialism roots, she can be seen as becoming a hybrid state. What this means for China's Danwei or other indigenous concepts and practices which may resemble SE (such as those outlined 4.1.3) offers considerable research potential.

\subsubsection{Intuitive-Aesthetic Strategy}

There are ample management theories that can further inform Chinese SE research. A wellknown characteristic of Greater China management is the practice that relies on intuitive, holistic and aesthetic thinking (Pun et al., 2000), wu (intuitive imagination), and guanxi or personal trust (Luo, 2003; Barney \& Zhang, 2009). These have some parallel with the Western literature on entrepreneurship and strategy called effectuation theory (Read et al., 2009; Sarasvathy, 2001). 
To-date, we do not know much about why Intuitive-Aesthetic Strategy, which is a mixture of effectuation and causation strategy plus some elements of aesthetics, is prevalent in Greater China management practices. This opens new avenues to conduct research on how the intuitiveaesthetics strategy and effectuation/causation strategy might be used, adapted, or fused with other strategies in the context of Chinese social enterprises, and their consequences.

\subsubsection{The Middle Way Strategy}

Another indigenous Greater China management practice is the Yin-Yang balance, or zhongyong (the golden rule of balanced harmony; Chen \& Miller, 2011), interpersonal harmony, or the 'both/and' logic (Li, 2014, 2012). These reflect the core of Greater China traditional philosophy about trying to be moderate and 'holding the middle' dynamically, avoiding imbalance and extremes. This is partly historical, where in response to the repeated defeat of China by Western powers; the Greater China society — in China, Hong Kong and Taiwan — learned from and imported Western social, political and economic systems. Consequently, the contemporary Greater China society becomes a hybrid adopter of external values and traditional cultures (Cheng et al., 2009).

Yin-Yang frame consists of three core tenets, which are 'holistic content', 'dynamic process', and 'duality integration' ( $\mathrm{Li}, 1998,2012)$. This, in the Western management context, would mean that Greater China social entrepreneurs may embrace paradox (Li, 1998) or Hegel's dialectical logic and, for instance, perceive 'co-opetition' instead of cooperation versus collaboration; 'ambidexterity' instead of exploration and exploitation (March, 1991); and 'glocalization' instead of globalization versus localization (Li, 2012). This Yin-and-Yang perspective can offer a new perspective to advance the research on hybrid organizing (Battilana \& Lee, 2014) in the Region and globally. It would also suggest that managing tensions may 
prove more natural to Greater China social entrepreneurs.

We do not suggest that future SE research should simply test and explore these specific indigenous concepts and practices (Section 4.2.1 to 4.2.3) but rather, to use them as examples of what we call promising concepts, ideas, theories and frameworks for future research. There are other indigenous concepts across different geographical contexts that scholars can use creatively. For example, in the Philippines, the Filipinos have a concept called 'Bayahinan', which refers to a spirit of togetherness and helping each other. This was a spirit that led to the rise of large-scale social enterprise such as Gawad Kalinga (Meloto, 2009). In Indonesia, religious values and aristocratic leadership (Idris \& Hati, 2013) are known to have pervasive influence on all aspects of life including as drivers of SE and these are useful for further exploration and testing by $\underline{\text { scholars. }}$

\subsubsection{Creative Imitation Strategy as Entrepreneurial Rebelliousness}

Another indigenous concept is called shanzhai (to copy then improve and extend; Lee \& Hung, 2014) or imitative innovation (Huang, Chou, \& Lee, 2010; Luo et al., 2011). Shanzhai symbolizes a resurgent of interest in the Chinese "robbers as heroes" culture of the past, which

refers to the wandering fighters, bandits and anti-establishment protagonists who escaped into

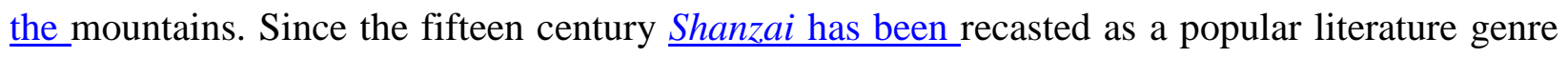
in the Chinese society (Hennessey, 2012). Shanzhai has been heralded as 'the sincerest form of rebellion in China' by the Wall Street Journal (Canaves and Ye, 2009). Therefore, the practices of shanzhai are not stigmatized (as an intellectual property violation) as it is in the West. Shanzhai also reflects the flourishing informal economy (or jiang-hu) in China, Hong Kong and Taiwan, and scholars found that shanzhai entrepreneurs are changing institutions by framing their products from "black" to shanzhai; aggregating their production and distribution to 
clustered locations; and bridging shanzhai producers with large Chinese companies and government agencies (Lee \& Hung, 2014) to enhance their legitimacy. Shanzai appears to resonate with bricolage (Baker \& Nelson, 2005) as a way of "making do with what is at hand" and “improvisation”. But more than just making do and improvising, shanzai enters the realm of market exchange between producers and buyers. To-date, we do not know how and why shanzhai is adopted, modified or fused by Greater China social enterprises, and how this influences their sustainability and ability to enact change.

\subsection{Exploring New Contexts}

\subsubsection{Internationalization and importation of $S E$}

The phenomenon of the internationalization of products and services has long been studied in international business and marketing literature (e.g., Katsikeas et al., 2006). However, there is little research on the role of internationalization and importation of SE into the Greater China region. There have been numerous imported social enterprises into the Region. Examples include The Big Issue, which has existed for more than a decade in Taiwan, and more recently Dignity Kitchen social enterprise that internationalized from Singapore to Hong Kong. It is public knowledge that almost no local SEs that have internationalized beyond the Region. Typical barriers to the internationalization of Greater China SEs have been the issues of adaptation to foreign markets, the difficulty in finding reliable partners, capital constraint, and the lack of labor. There are less costly ways to internationalize such as through franchising, trademarking, use of agents, or internetalization (Kim, 2020). Future research can examine the opportunity-founder nexus of the internationalization of Greater China SE (c.f., Chandra, 2017b; Shane \& Venkataraman, 2000), organization-beneficiary nexus (e.g. the relations between the SE 
and beneficiaries and local communities), the mode of entry of SE internationalization (e.g., joint venture versus direct investment versus licensing), to the influence of internationalization on the performance of social enterprises. There are many opportunities to study the drivers, process, and outcomes of social franchising (e.g., the case of Big Issue in the Region) and whether such franchising is a better approach than creative imitation. Another interesting aspect is to understand whether product/service adaptation of foreign SE models is needed, why and how. These are unchartered territories for future Greater China SE research.

\subsubsection{Expanding the Strategic Research Sites}

As explained earlier, Greater China SE scholarship has studied multiple strategic research sites (Merton, 1987), from poverty, rehabilitation, work-integration SE. These sites or contexts are very similar to those studied and published in the mainstream SE literature. Greater China SE research can be better integrated with the sustainability discourse and the United Nations' SDG goals, thus encouraging Greater China scholars to examine unique but lesser-studied contexts such as ageing, health crisis, suicide, natural disaster, water crisis, social conflict, refugee, terrorism, to waste problem, and climate change. Some scholars from the Region have started to push SE scholarship by framing their studies from a sectoral or contextual perspective like this, such as the study of SE in the context of HIV/AIDS (Chandra \& Shang, 2020) and post-disaster

environment (Paras, 2018). Re-contextualizing SE research along spatio-temporal, historical, linguistic, cultural, and institutional dimensions (Welter, 2011; Welter et al., 2019) offers new opportunities and confer advantages to local scholars who already have familiarity and access to such sites and contexts. 


\subsection{Retooling and Reskilling}

Our scoping review reveals the dominance of descriptive case studies as the methodology of choice by Greater China SE scholars, and to a smaller but newer extent, the use of quantitative methods such as surveys. This limitation in methodological apparatus is related to the nature of the training regime at the $\mathrm{PhD}$ curriculum in the Region as well as data availability and accessibility. There is an urgent need for SE scholars to retool, reskill and / or collaborate with others to expand their methodological toolboxes as a way to advance SE research. This might include using experimental social sciences, computational social sciences, and novel qualitative methods. For instance, more SE research can be done using laboratory and field experiments (c.f. Smith et al., 2012) to understand causality in SE, or using a less invasive approaches such as computational social sciences (c.f. Chandra et al., 2016; Imbert et al., 2019) to study strategy and interventions in SE. These are suitable to academics with good training in computer programming and quantitative skills. Those with psychological training can consider using automated voice recorders or new digital ethnographic techniques to observe the natural behavior of SE founders and employees (c.f., Mehl, 2017). In addition, those with creative minds can employ netnography (Kozinets, 2002) to study the online communities of SE. Overall, using new methodologies, scholars can see SE in a new way and study SE phenomena in a new way thus pushing the scholarship forward.

\section{CONCLUSION}

Social entrepreneurship (SE) as a field of practice and research is flourishing in the Greater China Region. However, there has been little efforts to systematically review what has been studied, what is known, the gaps in the field, and what opportunities lie ahead. In this article, we 
conducted a scoping review of peer-reviewed articles published on Greater China SE — those from China, Taiwan and Hong Kong.

Our analysis of the 46 articles that qualified for the scoping review reveals a few patterns. First, there has been a lack of novelty and new discovery in the Greater China SE scholarship thus far. Such scholarship is dominated by publications that focus on the things that are "obvious" from the eyes of global (Western) SE scholarship - from describing the models of SE (e.g., Tian et al., 2018) and the tensions in SE (e.g., Yin \& Chen, 2018; Zhao \& Han, 2019). Second, the Greater China SE scholarship has followed the "style and taste" of SE research in the West. This is evident in the broadly similar ways in which Greater China SE scholars define and frame SE in their studies (see the six definitions of SE in Table 1), the research questions asked (see the nine types of research questions in Table 2), the theoretical lenses employed (see Table 3), and the methodology used (see Table 4) - viz a viz mainstream SE research. These paint a picture that the state of Greater China SE scholarship is quite similar to where the mainstream SE scholarship was around 10 or more years ago. Finally, from our extensive search, there is limited Greater China SE research that has been published in the so-called top-tier journals in their respected fields (e.g., management, social work, public policy, sociology, and economics). In fact, a substantial_proportion of them were published in obscure journals. This, in our view, is related to the lack of novelty of Greater China SE research on the one hand, and the editorial strategy among top tier journals that favors novelty on the other. Overall, we can conclude that the Greater China SE scholarship is “stuck” and is in need of rescue. 
The lack of progress of Greater China SE scholarship can be attributed to, first, its 'liability of newness' (Stinchcombe, 1965) because SE is relatively a new field in the Region compared to those of other regions such as the West. Accordingly, scholars in the Region "play it safe” by following the more mature mainstream (Western) SE scholarship in order to publish their work. This leads to SE scholars in the Region failing to move beyond the dominant Western lens on the world inherent in this literature. This is unfortunate because the Region has a wellspring of indigenous ( $\mathrm{Li}$ et al., 2012) practices, concepts, constructs, contexts and philosophy that can contribute to and enrich the global SE discourse. The Region is also home to (or a strategic research site for) many complex social-environmental problems and these provide many opportunities to contribute to theory, policy and practice. Another taken-for-granted and rarely talked about matter is language barrier. Writing for international journals requires a high level of technical skill and doing so in one's second or third language does not confer any advantages for SE scholars in the Region. Last but not least, in the Region, SE is still considered a niche or lesser important domain than the more mature fields such as sociology, management/marketing, public administration, social work, and others. Therefore, it may take some time before it ‘crosses the chasm’ to an accelerated growth.

To address the gaps and deficiencies in the Greater China SE scholarship discussed above, we offer a new framework to advance Greater China SE scholarship. This comprises 1) broadening the scope of SE (i.e., social and systemic change, public behavioral change, and pluralistic organizing and organizations), 2) localizing through indigenous theoretical lenses and concepts (i.e., danwei, intuitive-aesthetic, middle-way, creative imitation), 3) exploring new contexts (i.e., internationalization and importation, expanding strategic research sites), and 4) re-tooling and 
reskilling (i.e., researchers to upgrade their tools and skill and pursue SE research using experimental social sciences, computational social sciences, and novel qualitative methods).

Such a framework requires SE scholars to pursue more out-of-the-box, original, and daring research to contribute to and engage in meaningful conversation with the mainstream SE scholarship. It is time for Greater China SE scholars to make their voice, and the voices of Greater China social entrepreneurs heard in the global SE discourse. Our call also applies to mainstream SE scholars who can fruitfully work with Chinese data and theories to shed light on the unique contextual insights that Greater China and other non-Western cultural practices can bring to our understanding of how social entrepreneurship might lead to positive social change.

With regards to this Special Issue on "Social Entrepreneurship in Context", we make two concluding remarks. First, context matters and this means that there are (always) indigenous ideas/practices/theories from each geographical region in the world that can contribute to SE scholarship. Hence, scholars in various parts of the world, from East and South East Asia, the Global South in South Asia, Latin America and Africa, to the former Soviet states should take the opportunity to explore and publish local ideas, practices and theories that can enrich the SE scholarship - instead of merely borrowing and replicating the ideas/theories/frameworks taken from the West.

Second, the global social entrepreneurship discourse often casts social entrepreneurship as a hero that fills in for "state, market and nonprofit failures". In our view, juxtaposing social entrepreneurship with "failed" state, market and nonprofit sectors is not useful because it will 
alienate social entrepreneurship as an exclusive actor of social progress. Instead, to tackle public problems and enable social progress (re: achieving SDG goals) requires an inclusive participation. We need social entrepreneurship to be a language and mindset employed by the citizen sector, the state, market and nonprofit sectors and as a glue to connect sectors and facilitate cross-sectoral collaborations that involve micro, meso and macro levels enablers of change (Van Wijk et al., 2019). 
Table 1: Defining Social Entrepreneurship

\begin{tabular}{|c|c|c|c|c|}
\hline \multirow{2}{*}{ No. } & \multicolumn{2}{|c|}{ Definition of SE from the Mainstream SE Literature } & \multirow{2}{*}{ Discipline Origin } & \multirow{2}{*}{ Seminal Paper } \\
\hline & Definition & Example & & \\
\hline \multirow[t]{2}{*}{1.} & \multirow{2}{*}{$\begin{array}{l}\text { Organizing approach and organizations that } \\
\text { combine social welfare and commercial logics }\end{array}$} & Hybrid organizing by combining commercial and social goals & Organization & Battilana \& Dorado (2010) \\
\hline & & Entrepreneurship for social purposes & Management & Mair \& Marti (2006) \\
\hline \multirow[t]{4}{*}{2.} & \multirow[t]{4}{*}{$\begin{array}{l}\text { Nonprofits or social work embracing business } \\
\text { practices }\end{array}$} & Marketization of nonprofits (nonprofits embracing business) & Nonprofit Studies & $\begin{array}{l}\text { Eikenberry \& Kluver } \\
\text { (2004) }\end{array}$ \\
\hline & & The business of social work & Social Work & Grey et al (2013) \\
\hline & & Social value creation & Business Ethics & Santos (2012) \\
\hline & & Providing solutions to social problems & Organization & Dacin et al (2011) \\
\hline 3. & Alternative development model & Alternative development model & Development Studies & Venot (2016) \\
\hline \multirow[t]{2}{*}{4.} & \multirow{2}{*}{$\begin{array}{l}\text { Citizen driven participatory governance as an } \\
\text { extension of the government arm }\end{array}$} & Third-party government & Public Administration & Jung et al (2016) \\
\hline & & Participatory governance & Public Administration & $\begin{array}{l}\text { Defourny \& Nyssens } \\
\text { (2012) }\end{array}$ \\
\hline 5. & A tool intended for social change & Enabling social change & Public Policy/Politics & Ganz et al (2018) \\
\hline
\end{tabular}

\begin{tabular}{|c|c|c|c|c|}
\hline \multirow{2}{*}{ No. } & \multicolumn{2}{|c|}{ Definition of SE from the Greater China SE Literature } & \multirow{2}{*}{ Discipline Origin } & \multirow{2}{*}{ Relevant Paper } \\
\hline & Definition & Example & & \\
\hline \multirow[t]{11}{*}{1.} & \multirow{11}{*}{$\begin{array}{l}\text { Organizing approach and organizations that } \\
\text { combine social welfare and commercial logics }\end{array}$} & Application of business to nonprofits & Management & Wang et al (2015) \\
\hline & & Hybrid organization seeking business and social objectives & Management & Wong \& Poon (2018) \\
\hline & & Business strategies to achieve philanthropic goals & Management & Zhao (2012) \\
\hline & & Hybrid identity organizations & Management & Hsieh et al (2017) \\
\hline & & Hybrid organization combining business and social logics & Organization & Zhao \& Han (2019) \\
\hline & & $\begin{array}{l}\text { Innovative, entrepreneurial acts in nonprofits, business, } \\
\text { public sectors }\end{array}$ & Entrepreneurship & Kao \& Huang (2015) \\
\hline & & Organizations pursuing social and commercial value & Public Policy & Chandra \& Wong (2016) \\
\hline & & $\begin{array}{l}\text { Organizations pursuing double bottom line (of mission and } \\
\text { profit) }\end{array}$ & Nonprofit Studies & Kuan et al (2011) \\
\hline & & $\begin{array}{l}\text { Organizations seeking to create social improvement and } \\
\text { profit }\end{array}$ & Social Work & Ho \& Chan (2011) \\
\hline & & $\begin{array}{l}\text { Entrepreneurs to create social value through innovation, } \\
\text { adaptation, learning }\end{array}$ & Management & Yiu et al (2014) \\
\hline & & A mix of charity and for-profit & Nonprofit Studies & Zhang (2015) \\
\hline
\end{tabular}




\begin{tabular}{|c|c|c|c|c|}
\hline \multirow{2}{*}{ No. } & \multicolumn{2}{|c|}{ Definition of SE from the Greater China SE Literature } & \multirow{2}{*}{ Discipline Origin } & \multirow{2}{*}{ Relevant Paper } \\
\hline & Definition & Example & & \\
\hline \multirow[t]{8}{*}{2.} & \multirow{8}{*}{$\begin{array}{l}\text { Nonprofits or social work embracing business } \\
\text { practices }\end{array}$} & Nonprofits embracing business (double bottom line) & Social Work & Chui et al (2019) \\
\hline & & $\begin{array}{l}\text { Nonprofits earning income, change making, participatory } \\
\text { governance }\end{array}$ & Nonprofit Studies & Leung et al (2019) \\
\hline & & Commercialization of nonprofits & Social Work & Tian et al (2018) \\
\hline & & Solving problems using entrepreneurship & Management & Yin \& Chen (2018) \\
\hline & & Nonprofits with a commercial strategy & Public Policy & $\mathrm{Yu}(2013)$ \\
\hline & & Socially entrepreneurial nonprofit & Public Policy & Yu (2016) \\
\hline & & Using business to address social problems & Economics & Warnecke (2018) \\
\hline & & Business approach applied to achieve social mission & Nonprofit Studies & Chan et al (2011) \\
\hline \multirow[t]{2}{*}{3.} & \multirow[t]{2}{*}{ Collective enterprise ownership in the rural areas } & $\begin{array}{l}\text { Rural enterprises creating business and welfare for } \\
\text { communities }\end{array}$ & Management & Poon et al (2009) \\
\hline & & $\begin{array}{l}\text { Rural cooperatives with social mission and common } \\
\text { prosperity goals }\end{array}$ & Management & Lan et al (2014) \\
\hline 4. & Danwei (a social resource distributor) & Danwei (work unit) as a social resource distributor & Political Economy & Curtis (2011) \\
\hline \multirow[t]{2}{*}{5.} & \multirow{2}{*}{$\begin{array}{l}\text { Sustainability with social-commercial-ecological } \\
\text { value creation }\end{array}$} & A tool to achieve sustainable local development & Tourism & Zeng (2018) \\
\hline & & \begin{tabular}{|l} 
Nonprofits creating social, economic, environmental value \\
\end{tabular} & Tourism & Wang et al (2016) \\
\hline 6. & Institutional change work & Institutional change work & Management & Chandra (2017) \\
\hline
\end{tabular}


Table 2: Research Questions in Greater China SE Scholarship

\begin{tabular}{|c|c|c|}
\hline $\begin{array}{c}\text { Categories of Research Questions } \\
\text { Asked }\end{array}$ & Typical Example of Research Questions Asked & Relevant Authors \\
\hline Antecedents & "What drive success in SE"; "Determinants of SE intention" & $\begin{array}{l}\text { Lan et al (2014); Yang et al. (2015); Zheng et al. } \\
\text { (2020); Yu \& Wang (2019); Hsu \& Wang (2019). }\end{array}$ \\
\hline Emergence and development process & $\begin{array}{l}\text { "The types of SE operational models"; "Tensions in SE scaling process"; } \\
\text { "Motivations to pursue SE"; "Role of networks and bricolage in SE } \\
\text { formation"' "How SE obtains legitimacy"; "SE institutional change } \\
\text { process" }\end{array}$ & $\begin{array}{l}\text { Tian et al. (2018); Bhatt et al. (2019); Curtis (2011); } \\
\text { Zhao \& Han (2019); Yiu et al. (2014); Liu et al. } \\
\text { (2020); Xu \& Xi (2020); Jian (2017); Chandra (2017). }\end{array}$ \\
\hline Outcomes & $\begin{array}{l}\text { "How SE brings institutional change"; "Testing value co-creation on SE } \\
\text { growth"; "Influence of business model innovation on SE performance"; } \\
\text { "Exploring the performance of social enterprises"; "Exploring the social } \\
\text { impact of SE"; "Examining SE profitability"; "Exploring the role of SE } \\
\text { on pro-poor tourism" }\end{array}$ & $\begin{array}{l}\text { Warnecke (2018); Ge et al. (2019); Wang \& Zhou } \\
\text { (2020); Wong \& Poon (2018); Ho \& Chan (2010); } \\
\text { Leung et al. (2019); Leung, Mo, Ling, Chandra, \& Ho } \\
\text { (2019); Zeng (2018). }\end{array}$ \\
\hline History & "Exploring the development of a SE in China's tourism industry" & Wang et al. (2016). \\
\hline Boundary condition testing & $\begin{array}{l}\text { "Testing how empowerment HR practices influence employees' work } \\
\text { engagement in SE"; "Testing the mediating role of creativity on SE } \\
\text { intention" }\end{array}$ & Zhang et al. (2018); Ip et al. (2018). \\
\hline Problems and challenges facing SE & $\begin{array}{l}\text { "Challenges faced by SE in China"; "Dilemmas confronting social } \\
\text { entrepreneurs in China" }\end{array}$ & Wang et al. (2015); Wong \& Tang (2006). \\
\hline Managing tensions & "How social enterprises balances social and economic goals" & Yin \& Chen (2019). \\
\hline Comparative studies & $\begin{array}{l}\text { "Differences in the SE certification in China, Hong Kong, and Taiwan"; } \\
\text { "Similarities and differences of SE in Taiwan and Hong Kong"; "The } \\
\text { governance of SE in Taiwan and Hong Kong" }\end{array}$ & $\begin{array}{l}\text { Luo \& Huang (2019); Chan et al. (2011); Kuan et al. } \\
\text { (2011). }\end{array}$ \\
\hline SE characteristics & $\begin{array}{l}\text { "The differences of work in SE compared to social service agencies"; } \\
\text { "The meaning of employment for the disadvantaged in SE"; "The role of } \\
\text { family in SE"; "Operational characteristics of SE" }\end{array}$ & $\begin{array}{l}\text { Chui et al. (2019); Dai et al. (2017); Kao \& Huang } \\
\text { (2015); Wu et al. (2018). }\end{array}$ \\
\hline
\end{tabular}


Table 3: Theories Used in Social Entrepreneurship Research

\begin{tabular}{|c|c|c|c|}
\hline $\begin{array}{l}\text { Theories Used in the } \\
\text { Mainstream SE Scholarship }\end{array}$ & Main Idea & Example & Seminal Papers \\
\hline Institutional Theory & $\begin{array}{l}\text { Formal and informal institutions shape the } \\
\text { emergence, type and strategies of SE. }\end{array}$ & $\begin{array}{l}\text { The UK and US's SE sector came from different } \\
\text { institutional roots; SE as a hybrid logic. }\end{array}$ & $\begin{array}{l}\text { Kerlin (2017); Battilana \& } \\
\text { Dorado (2010) }\end{array}$ \\
\hline Empowerment & $\begin{array}{l}\text { Oppressed individuals can be given the "ability to } \\
\text { make choices" in their lives through resources, } \\
\text { agency, achievement. }\end{array}$ & $\begin{array}{l}\text { Poor women in India are empowered through } \\
\text { cooperatives and SE. }\end{array}$ & $\begin{array}{l}\text { Datta \& Gailey, 2012; Haugh } \\
\text { \& Talwar (2016) }\end{array}$ \\
\hline Compassion/Altruism & $\begin{array}{l}\text { The emotion "to suffer together" and the desire to } \\
\text { benefit others drive individuals to become social } \\
\text { entrepreneurs. }\end{array}$ & $\begin{array}{l}\text { Compassion is a key driver for people to become } \\
\text { social entrepreneurs. }\end{array}$ & $\begin{array}{l}\text { Miller et al (2012); Germak } \\
\text { \& Robinson (2014) }\end{array}$ \\
\hline Resource Based View & $\begin{array}{l}\text { Unique and valuable resources assembled by } \\
\text { organizations are needed to achieve sustainable } \\
\text { competitive advantage. }\end{array}$ & $\begin{array}{l}\text { Social entrepreneurs require resources to succeed: } \\
\text { engage stakeholders, attract gov't support, generate } \\
\text { earned-income. }\end{array}$ & $\begin{array}{l}\text { Meyskens et al (2010); Bacq } \\
\text { \& Eddleston (2018) }\end{array}$ \\
\hline Meaningful Work & $\begin{array}{l}\text { Work is a calling and therefore has social and moral } \\
\text { meanings to make positive contribution to the world. }\end{array}$ & $\begin{array}{l}\text { SE seems like a meaningful work but involves lack } \\
\text { of work/life balance, underpaid labour etc. }\end{array}$ & Dempsey \& Sanders (2010) \\
\hline Narrative/Rhetoric & $\begin{array}{l}\text { Actor seeking to create change use certain } \\
\text { language/rhetoric to achieve their goals. }\end{array}$ & $\begin{array}{l}\text { Social entrepreneurs employ certain rhetorical } \\
\text { strategy to achieve legitimacy to create social } \\
\text { change. }\end{array}$ & $\begin{array}{l}\text { Ruebottom (2013); Parkinsor } \\
\text { \& Howorth (2008) }\end{array}$ \\
\hline Effectuation Theory & $\begin{array}{l}\text { Entrepreneurs use non-predictive mode of thinking } \\
\text { to deal with uncertainty by leveraging self-identity, } \\
\text { hobby, networks, exploiting contingencies than } \\
\text { planning. }\end{array}$ & $\begin{array}{l}\text { Effectuation to overcome resource constraints, } \\
\text { causation to ensure efficiency and sustainability. }\end{array}$ & $\begin{array}{l}\text { Servantie \& Rispal (2018); } \\
\text { Corner \& Ho (2010) }\end{array}$ \\
\hline Bricolage & $\begin{array}{l}\text { Creating something out of nothing by repurposing, } \\
\text { finding new use, use other's resources, use idle } \\
\text { resources. }\end{array}$ & $\begin{array}{l}\text { Bricolage helps SEs mobilize resources to achieve } \\
\text { legitimacy. }\end{array}$ & $\begin{array}{l}\text { Desa \& Basu (2013); Desa } \\
\text { (2012) }\end{array}$ \\
\hline Identity Theory & $\begin{array}{l}\text { All organizations possess identity to deal with } \\
\text { tensions inside and outside them. }\end{array}$ & $\begin{array}{l}\text { Organizations working on sensitive social issue may } \\
\text { be stigmatized and need identity work to gain } \\
\text { stakeholder support. }\end{array}$ & Tracey \& Phillips (2016) \\
\hline
\end{tabular}




\begin{tabular}{|c|c|c|c|}
\hline $\begin{array}{l}\text { Theories Used in Greater China } \\
\text { SE Scholarship }\end{array}$ & Main Idea & Example & Relevant Paper(s) \\
\hline $\begin{array}{l}\text { Sociology: institutional theory, } \\
\text { structuration theory, socialism } \\
\text { theory, identity theory. }\end{array}$ & $\begin{array}{l}\text { The structure constrains and be influenced by the } \\
\text { agent. }\end{array}$ & $\begin{array}{l}\text { Why there are few social enterprises in China; how } \\
\text { social enterprises drive institutional change in } \\
\text { China; SE certification differences in the Region. }\end{array}$ & $\begin{array}{l}\text { Bhatt et al (2019); Warnecke } \\
\text { (2018); Luo \& Huang 92019) }\end{array}$ \\
\hline $\begin{array}{l}\text { Psychology: theory of moral } \\
\text { sentiments, self-determination } \\
\text { theory, theory of planned } \\
\text { behavior. }\end{array}$ & $\begin{array}{l}\text { Individual level factors that drive or motivate } \\
\text { people to become social entrepreneurs. }\end{array}$ & $\begin{array}{l}\text { Previous distressing life experience can drive } \\
\text { people to embrace SE or find value in work; } \\
\text { intention drive. }\end{array}$ & $\begin{array}{l}\text { Yiu et al 2014); Zhang et al } \\
\text { (2018); Yang et al (2015) }\end{array}$ \\
\hline $\begin{array}{l}\text { Economics: development theory, } \\
\text { welfare theory. }\end{array}$ & $\begin{array}{l}\text { SE plays a role in rural economic development and } \\
\text { welfare provider. }\end{array}$ & $\begin{array}{l}\text { Rural poverty as addressed by social enterprises; } \\
\text { the role of religious organizations in providing } \\
\text { welfare goods and services. }\end{array}$ & Lan et al (2014); Zang (2015) \\
\hline $\begin{array}{l}\text { Management/Organizational } \\
\text { Behavior: cooperative theory, } \\
\text { paradox theory, governance } \\
\text { theory, value co-creation theory, } \\
\text { organizational ecology theory. }\end{array}$ & $\begin{array}{l}\text { There exist certain good management and } \\
\text { governance practices that can help social } \\
\text { enterprises to achieve their goals. }\end{array}$ & $\begin{array}{l}\text { The transformation of nonprofits into social } \\
\text { enterprise model; the balancing of social versus } \\
\text { economic goals in SE. }\end{array}$ & $\begin{array}{l}\text { Chen (2011); Yin \& Chen } \\
\text { (2019); Kuan et al (2011) }\end{array}$ \\
\hline $\begin{array}{l}\text { Social work: empowerment } \\
\text { theory. }\end{array}$ & $\begin{array}{l}\text { SE as an enabler of empowerment to marginalized } \\
\text { community members. }\end{array}$ & $\begin{array}{l}\text { Work integration social enterprises (WISEs) as the } \\
\text { most popular form of SE in a new public } \\
\text { management oriented region such as Hong Kong. }\end{array}$ & $\begin{array}{l}\text { Chui et al (2019); Chandra } \\
\text { (2017); Zhang et al (2018) }\end{array}$ \\
\hline $\begin{array}{l}\text { Concepts: bricolage, business } \\
\text { model innovation, organizational } \\
\text { life cycle, venture philanthropy or } \\
\text { crowdfunding }\end{array}$ & $\begin{array}{l}\text { Relatively new organizational practices to access } \\
\text { resources and to innovate SE. }\end{array}$ & $\begin{array}{l}\text { Bricolage to access resources for SE; funding } \\
\text { strategies of SE; business model innovation } \\
\text { improves SE performance. }\end{array}$ & $\begin{array}{l}\text { Liu et al (2020); Zheng (2018); } \\
\text { Wang \& Zhou (2020) }\end{array}$ \\
\hline Danwei & $\begin{array}{l}\text { Danwei as a form of work unit under the socialist } \\
\text { economy that contains social security (e.g., } \\
\text { education, employment, health care, and retirement } \\
\text { care) for residents. It is the SE without calling one } \\
\text { as such. }\end{array}$ & $\begin{array}{l}\text { The hybrid organizing structure for community } \\
\text { members under the socialist economy. }\end{array}$ & Curtis (2011) \\
\hline
\end{tabular}


Table 4: Methodologies Used in the Greater China SE Scholarship

\begin{tabular}{|l|l|l|l||}
\hline Methodology Used & \multicolumn{1}{|c|}{ Type(s) of Data } & \multicolumn{1}{|c|}{ Analytical Techniques } & \multicolumn{1}{|c|}{ Relevant Paper(s) } \\
\hline \hline Case study & $\begin{array}{l}\text { In-depth interviews; informal interviews via } \\
\text { telephone, email, face to face conversation; websites } \\
\text { and news reports. }\end{array}$ & $\begin{array}{l}\text { Manual coding; thematic analysis using Nvivo } \\
\text { with open and axial coding; the Gioia approach } \\
\text { in presenting and displaying data. }\end{array}$ & $\begin{array}{l}\text { Zhao \& Han (2019); Chui et al } \\
\text { (2019); Kao \& Huang (2015). }\end{array}$ \\
\hline Survey & $\begin{array}{l}\text { Close-form response using online and paper-based } \\
\text { surveys. }\end{array}$ & $\begin{array}{l}\text { Descriptive statistics, exploratory and } \\
\text { confirmatory factor analysis, interaction } \\
\text { analysis, regressions, structural equation } \\
\text { modelling. }\end{array}$ & $\begin{array}{l}\text { Yang et al (2015); Yiu et al (2014); } \\
\text { Zhang et al (2018) }\end{array}$ \\
\hline Corpus linguistics & $\begin{array}{l}\text { Media discourse, blogs, magazines, websites as } \\
\text { corpus data; large scale interview data. }\end{array}$ & $\begin{array}{l}\text { Keyness analysis, semantic category analysis, } \\
\text { collocation, keyword in context analysis } \\
\text { (concordance). }\end{array}$ & Chandra (2017) \\
\hline Ethnography & Observation, in-depth interviews. & Manual coding & Dai et al (2017) \\
\hline \hline
\end{tabular}




\section{Appendix:}

\section{Results of the Search and Study Selection Process}

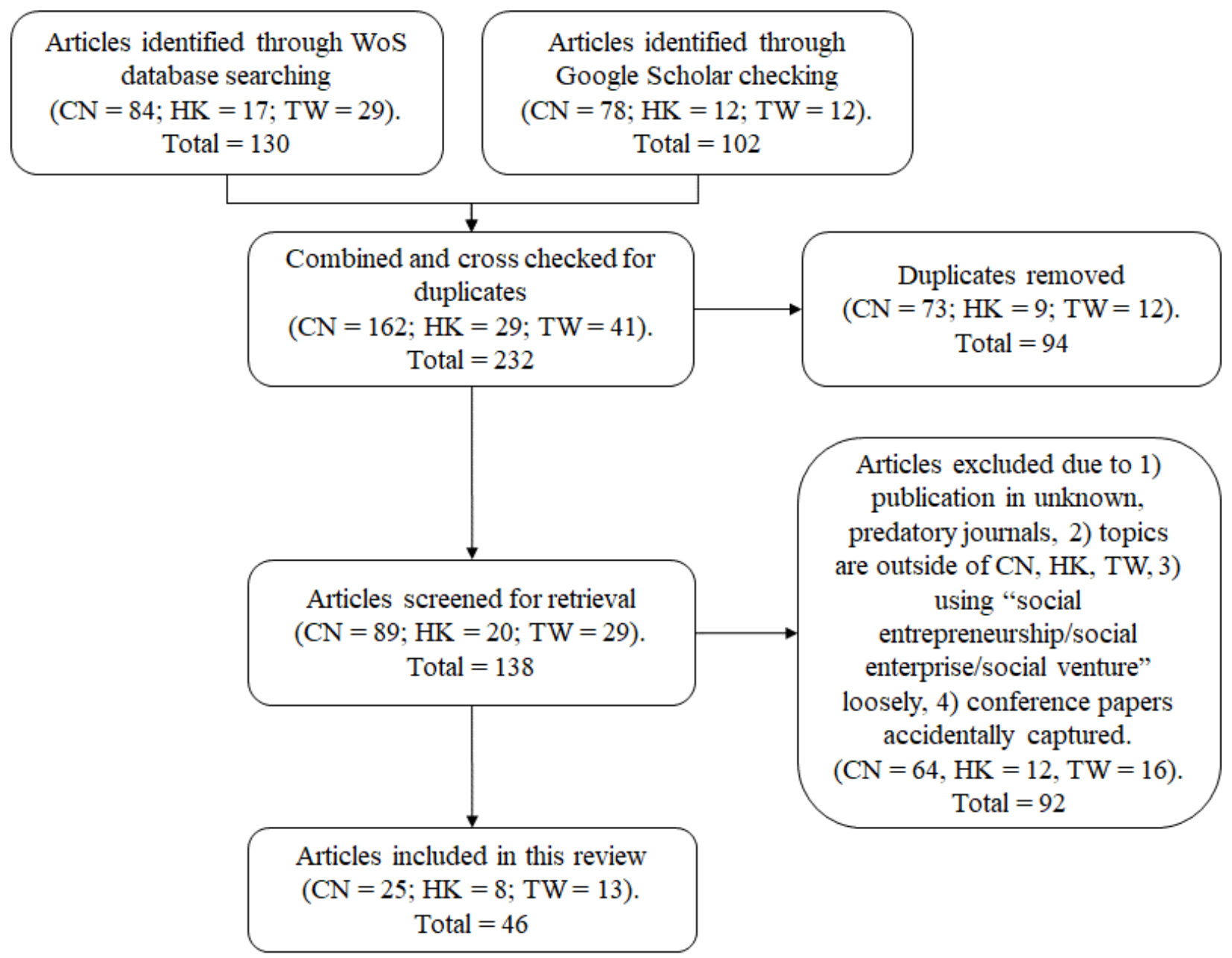




\section{References}

Agrawal, A., \& Hockerts, K. (2019). Impact investing: Review and research agenda. Journal of Small Business \& Entrepreneurship_ (online first version). https://doi.org/10.1080/08276331.2018.1551457

Almestahiri, R. D., Rundle-Thiele, S., Parkinson, J., \& Arli, D. (2017). The use of the major components of social marketing: A systematic review of tobacco cessation programs. Social Marketing Quarterly, 23(3), 232-248.

Andreasen, A. R. (2002). Marketing social marketing in the social change marketplace. Journal of Public Policy \& Marketing, 21(1), 3-13.

Arksey, H., \& O'Malley, L. (2005). Scoping studies: towards a methodological framework. International Journal of Social Research Methodology, 8(1), 19-32.

Austin, JE., \& Reffico, E. (2009). Corporate Social Entrepreneurship. Harvard Business School Working Paper Summaries. Downloaded on 22 July 2020 from: https://hbswk.hbs.edu/item/corporate-social-entrepreneurship

Baker, T., \& Nelson, R. E. (2005). Creating something from nothing: Resource construction through entrepreneurial bricolage. Administrative Science Quarterly, 50(3), 329-366.

Barney, J., \& Zhang, Z. (2009). The future of Chinese management research: A theory of Chinese management versus a Chinese theory of management. Management and Organization Review, 5(1), 15-28.

Battilana, J., \& Dorado, S. (2010). Building sustainable hybrid organizations: The case of commercial microfinance organizations. Academy of Management Journal, 53 (6), 14191440.

Bartlett, D., \& Dibben, P. (2002). Public sector innovation and entrepreneurship: Case studies from local government. Local Government Studies, 28(4), 107-121.

Canaves S, Ye J. (2009). Imitation is the sincerest form of rebellion in China. Wall Street Journal, 22 January 2020. Available at: http://online.wsj.com/article/ SB123257138952903561.html (accessed 18 April 2013).

Chan, C. H., Chui, C. H. K., Chan, K. S. T., \& Yip, P. S. F. (2019). The role of the social innovation and entrepreneurship development fund in fostering social entrepreneurship in Hong Kong: A study on public policy innovation. Social Policy \& Administration, 53(6), 903-919.

Chan, KM., \& Yuen, T.Y.K. (2013). An overview of social enterprise development in China and Hong Kong. Journal of Ritsumeikan Social Sciences and Humanities, 5(13), 165-178.

Chan, K. T., Kuan, Y. Y., \& Wang, S. T. (2011). Similarities and divergences: Comparison of social enterprises in Hong Kong and Taiwan. Social Enterprise Journal, 7(1), 33-49.

Chen, C. C., Chen, X.-P., \& Huang, S. (2013). Chinese Guanxi: An integrative review and new directions for future research. Management and Organization Review, 9(1), 167-207.

Chen, M.-J., \& Miller, D. (2011). The relational perspective as a business mindset: Managerial implications for East and West. Academy of Management Perspectives, 25(3), 6-18.

Cheng, B. S., Wang, A. C., \& Huang, M. P. (2009). The road more popular versus the road less travelled: An 'insider's' perspective of advancing Chinese management research. Management and Organization Review, 5(1), 91-105.

Chandra, Y., \& Paras, A. (2020). Social entrepreneurship in the context of disaster recovery: Organizing for public value creation. Public Management Review (online first version). https://doi.org/10.1080/14719037.2020.1775282 
Chandra, Y. (2017a). Social entrepreneurship as institutional-change work: A corpus linguistics analysis. Journal of Social Entrepreneurship, 8(1), 14-46.

Chandra, Y. (2017b). A time-based process model of international entrepreneurial opportunity evaluation. Journal of International Business Studies, 48(4), 423-451.

Chandra, Y., Jiang, Li., \& Wang, C-J. (2016). Mining social entrepreneurship strategies using topic modeling. PLosONE, 11(3), e0151342.

Chandra, Y., \& Wong, L (2016). Social Entrepreneurship in the Greater China: Policy and Cases. Routledge, United Kingdom.

Chandra, Y., \& Shang, L. (2019). Philanthropy research in china: The influence of informal institutions. Third Sector Review, 25(1), 105-122.

CSESC (2020). China Social Enterprise Service Center. Accessed on 20 May 2020 from: http://www.sirf2019-exhibition.hk/portfolio/03/

Dees, G. (1998). The meaning of social entrepreneurship. Accessed on 20 May 2020 from http:// www.fuqua.duke.edu/centers/case/documents/dees_SE.pdf.

Dees, J. G., \& Elias, J. (1998). The challenges of combining social and commercial enterprise. Business Ethics Quarterly, 8(1), 165-178.

Defourny, J., \& Kim, S. Y. (2011). Emerging models of social enterprise in Eastern Asia: A cross-country analysis. Social Enterprise Journal, 7(1), 86-111.

Denis JL, Dompierre G, Langley A, Rouleau L (2011) Escalating indecision: Between reification and strategic ambiguity. Organization Science, 22(1), 225-244.

Dixon-Woods, M., Bonas, S., Booth, A., Jones, D. R., Miller, T., Sutton, A. J., ... \& Young, B. (2006). How can systematic reviews incorporate qualitative research? A critical perspective. Qualitative Research, 6(1), 27-44.

Doherty, B., Haugh, H., \& Lyon, F. (2014). Social enterprises as hybrid organizations: A review and research agenda. International Journal of Management Reviews, 16(4), 417-436.

Elkington, J. (2006). Governance for sustainability. Corporate Governance: An International Review, 14(6), 522-529.

Firestone, R., Rowe, C. J., Modi, S. N., \& Sievers, D. (2017). The effectiveness of social marketing in global health: A systematic review. Health Policy and Planning, 32(1), 110124.

Ganz, M., Kay, T., \& Spicer, J. (2018). Social enterprise is not social change. Stanford Social Innovation Review, 16, 59-60.

Gehman, J., Glaser, V. L., Eisenhardt, K. M., Gioia, D., Langley, A., \& Corley, K. G. (2018). Finding theory-method fit: A comparison of three qualitative approaches to theory building. Journal of Management Inquiry, 27(3), 284-300.

$\mathrm{Gu}, \mathrm{Y}$. (2012). Major issues in social enterprise development in the Mainland China. Accessed on 20 May 2020 from: https://hksef.org/2012/12/major-issues-in-social-enterprisedevelopment-in-the-mainland-china/

Grant, M. J., \& Booth, A. (2009). A typology of reviews: An analysis of 14 review types and associated methodologies. Health Information \& Libraries Journal, 26(2), 91-108.

Gupta, P., Chauhan, S., Paul, J., \& Jaiswal, M. P. (2020). Social entrepreneurship research: A review and future research agenda. Journal of Business Research (online first version). https://doi.org/10.1016/j.jbusres.2020.03.032

Hazenberg, R., Bajwa-Patel, M., Roy, M. J., Mazzei, M., \& Baglioni, S. (2016). A comparative overview of social enterprise 'ecosystems' in Scotland and England: An evolutionary perspective. International Review of Sociology, 26(2), 205-222. 
Hennessey, W. (2012). Deconstructing shanzhai - China's copycat counterculture: Catch me if you can. Campbell Law Review, 34: 609.

HKFP (2018). Ming-gor runs a Sham Shui Po restaurant with a difference: profits are not on the menu. Hong Kong Free Press, 18 February 2018. https://hongkongfp.com/2018/02/18/minggor-runs-sham-shui-po-restaurant-difference-profits-not-menu/

Hong Kong Social Enterprise Endorsement Mark. https://seemark.hk/en_gb/

Ho, A. P. Y., \& Chan, K. T. (2010). The social impact of work-integration social enterprise in Hong Kong. International Social Work, 53(1), 33-45.

Idris, A., \& Hijrah Hati, R. (2013). Social entrepreneurship in Indonesia: Lessons from the past. Journal of Social Entrepreneurship, 4(3), 277-301.

Imbert, E., Morone, P., \& Bigi, F. (2019). Assessing the potential of social enterprises through social network analysis-Evidence from Albania. Journal of Evolutionary Economics, 29(4), 1211-1239.

Jones, M. V., Coviello, N., \& Tang, Y. K. (2011). International entrepreneurship research (19892009): A domain ontology and thematic analysis. Journal of Business Venturing, 26(6), 632659.

Katsikeas, C. S., Samiee, S., \& Theodosiou, M. (2006). Strategy fit and performance consequences of international marketing standardization.Strategic Management Journal, 27(9), 867-890.

Kee, C.H. (2016). Developing Social Workers to Run Social Enterprises. Ed.D thesis, University of Nottingham. Downloadable: http://eprints.nottingham.ac.uk/33473/

Kim, D. (2020). Internet and SMEs' internationalization: The role of platform and website. Journal of International Management, 26(1), 100690.

Kozinets, R. V. (2002). The field behind the screen: Using the method of netnography to research market-oriented virtual communities. Journal of Consumer research, 39(1), 61-72.

Kuan, Y.-Y. and Wang, S.-T. (2015) “Social Enterprise in Taiwan”, ICSEM Working Papers, No. 13, Liege: The International Comparative Social Enterprise Models (ICSEM) Project.

Kuan, Y. Y., Chan, K. T., \& Wang, S. T. (2011). The governance of social enterprise in Taiwan and Hong Kong: A comparison. Journal of Asian Public Policy, 4(2), 149-170.

Lee, C. K., \& Hung, S. C. (2014). Institutional entrepreneurship in the informal economy: China's shan-zhai mobile phones. Strategic Entrepreneurship Journal, 8(1), 16-36.

Lane, A. (2012). China Social Enterprise Report by FYSE. Hong Kong, China.

Leadbetter, C. (1997). The rise of the social entrepreneur. London: Demos.

Lee, R. (2009). The emergence of social enterprises in China: The quest for space and legitimacy. Tsinghua China Law Review, 2(79), 80-99.

Lee, N. R., \& Kotler, P. (2019). Social marketing: Behavior change for social good. SAGE Publications.

Lee, H. L., Hwang, E. J., Wu, S. L., Tu, W. M., Wang, M. H., \& Chan, F. (2018). Employment outcomes after vocational training for people with chronic psychiatric disorders: A multicenter study. American Journal of Occupational Therapy, 72(5), 7205195010p1$7205195010 p 9$.

Li, P. P. (2014). The unique value of yin-yang balancing: A critical response. Management and Organization Review, 10(2), 321-332.

Li, P. P. (2012). Toward an integrative framework of indigenous research: The geocentric implications of Yin-Yang Balance. Asia Pacific Journal of Management, 29(4), 849-972. 
Li, P. P., Leung, K., Chen, C. C., \& Luo, J. D. (2012). Indigenous research on Chinese management: What and how. Management and Organization Review, 8(1), 7-24.

Li, P. P. (1998). Toward a geocentric framework of organizational form: A holistic, dynamic and paradoxical approach. Organization Studies, 19(5), 829-861.

Lodhia, S., Martin, N., \& Rice, J. (2017). Extended Producer Responsibility for waste televisions and computers: A regulatory evaluation of the Australian experience. Journal of Cleaner Production, 164, 927-938.

Luo, Y., Sun, J., \& Lu, S. C. (2011). Emerging economy copycats: Capability, environment and strategy. Academy of Management Perspective, 25(2), 37-56.

Luo, Y. (2003). Industrial dynamics and managerial networking in an emerging market: The case of China. Strategic Management Journal, 24(13), 1315-1327.

Mair, J., \& Marti, I. (2006). Social entrepreneurship research: A source of explanation, prediction, and delight. Journal of World Business, 41(1), 36-44.

March, J. G. (1991). Exploration and exploitation in organizational learning. Organization Science, 2(1), 71-87.

Martin, R.L., \& Osberg, S. (2007). Social entrepreneurship: The case for definition. Stanford Social Innovation Review, Spring, 27-39.

Mehl, M. R. (2017). The electronically activated recorder (EAR) a method for the naturalistic observation of daily social behavior. Current Directions in Psychological Science, 26(2), 184-190.

Meloto, A. (2009). Builder of Dreams. Mandaluyong City: Gawad Kalinga Community Development Foundation, Inc.

Merton, R.K. (1987). Three fragments from a sociologist's notebooks: Establishing the phenomenon, specified ignorance, and strategic research materials. Annual Review of Sociology, 13(1), 1-29.

Mintrom, M., \& Norman, P. (2009). Policy entrepreneurship and policy Change. Policy Studies Journal, 37(4), 649-667.

Moore, M. H. (1995). Creating Public Value: Strategic Management in Government. Cambridge, MA: Harvard University Press.

Munn, Z., Peters, M. D., Stern, C., Tufanaru, C., McArthur, A., \& Aromataris, E. (2018). Systematic review or scoping review? Guidance for authors when choosing between a systematic or scoping review approach. BMC Medical Research Methodology, 18(1), 143.

Nestle: Creating Shared Value 2013. Nestle China CSV Report. https://www.nestle.com/sites/default/files/assetlibrary/documents/library/documents/corporate_social_responsibility/nestle-china-csv-report2013.pdf

Nicholls, A., \& Teasdale, S. (2019). Dynamic persistence in UK policy making: The evolution of social investment ideas and policy instruments. Public Management Review (online first review). https://doi.org/10.1080/14719037.2019.1699948

Paras, A. (2018). Essays on Post-disaster Social Entrepreneurship: Founders, Beneficiaries and the Process of Effectuation (Doctoral dissertation, City University of Hong Kong).

Poon, P. S., Zhou, L., \& Chan, T. (2009). Social entrepreneurship in a transitional economy entrepreneurial firms. Journal of Management Development, 28(2), 94-108.

Pun, K. F., Chin, K. S., \& Lau, H. (2000). A review of the Chinese cultural influences on Chinese enterprise management. International Journal of Management Reviews, 2(4), 325338. 
Ramos-Rodríguez, A. R. and J. Ruíz-Navarro. 2004. Changes in the intellectual structure of strategic management research: a bibliometric study of the Strategic Management Journal, 1980-2000. Strategic Management Journal, 25(10), 981-1004.

Read, S., Song, M., \& Smit, W. (2009). A meta-analytic review of effectuation and venture performance. Journal of Business Venturing, 24(6), 573-587.

Saebi, T., Foss, N. J., \& Linder, S. (2019). Social entrepreneurship research: Past achievements and future promises. Journal of Management, 45(1), 70-95. https://doi.org/10.1177/0149206318793196

Salamon, L. M. (1987). Of market failure, voluntary failure, and third-party government: Toward a theory of government-nonprofit relations in the modern welfare state. Journal of Voluntary Action Research, 16(1-2), 29-49.

Sarasvathy, S. D. (2001). Causation and effectuation: Toward a theoretical shift from economic inevitability to entrepreneurial contingency. Academy of Management Review, 26(2), 243263.

Shane, S., \& Venkataraman, S. (2000). The promise of entrepreneurship as a field of research. Academy of Management Review, 25(1), 217-226.

Shepherd, D. A., \& Suddaby, R. (2017). Theory building: A review and integration. Journal of Management, 43(1), 59-86.

Short, J. C., Moss, T. W., \& Lumpkin, G. T. (2009). Research in social entrepreneurship: Past contributions and future opportunities. Strategic Entrepreneurship Journal, 3(2), 161-194.

Smith, B. R., Cronley, M. L., \& Barr, T. F. (2012). Funding implications of social enterprise: The role of mission consistency, entrepreneurial competence, and attitude toward social enterprise on donor behavior. Journal of Public Policy \& Marketing, 31(1), 142-157.

Social Enterprise Insights Asia. SE in Taiwan: A Golden Decade of Social Enterprise in Taiwan the Silent Revolution. http://en.seinsights.asia/seintaiwan/

Social Enterprise Hong Kong. Accessed on 22 July 2020 from: https://www.sehk.gov.hk/en/award.html

Social Enterprise Business Centre. Accessed on 22 July 2020 from: https://www.socialenterprise.org.hk/en

Social Enterprise Insights Asia (2020). Accessed on 22 July 2020 from: http://en.seinsights.asia/seintaiwan/

Stinchcombe, A.L. (1965). Social structure and organizations. In March, J. (Ed.), Handbook of Organizations, Rand McNally, Chicago, IL, pp. 142-93.

Tang, K. L., Fung, H. L., Au, K. Y., Lee, J. K. C., \& Ko, L. S. (2008). Social enterprises in Hong Kong: Toward a conceptual model. Final report submitted to Central Policy Unit of the Government of the Hong Kong Special Administration Region of the People's Republic of China.

Taiwan NPO Self-Regulation Alliance. Accessed on 22 May 2020 from https://www.twnpos.org.tw/

The Standard. (2019). Ming Gor's free meal to come in more districts. The Standard, 29 December 2019. https://www.thestandard.com.hk/breaking-news/section/3/139147/MingGor\&

Tucker, J. D., Muessig, K. E., Cui, R., Bien, C. H., Lo, E. J., Lee, R., ... \& Yang, B. (2014). Organizational characteristics of HIV/syphilis testing services for men who have sex with men in South China: A social entrepreneurship analysis and implications for creating sustainable service models. BMC Infectious Diseases, 14(1), 601. 
Venot, J. P. (2016). A success of some sort: Social enterprises and drip irrigation in the developing world. World Development, 79, 69-81.

Welter, F. (2011). Contextualizing entrepreneurship-conceptual challenges and ways forward. Entrepreneurship Theory and Practice, 35(1), 165-184.

Welter, F., Baker, T., \& Wirsching, K. (2019). Three waves and counting: The rising tide of contextualization in entrepreneurship research. Small Business Economics, 52(2), 319-330.

Yang, Y. K. (2016). An exploration of ambiguity logic in organizations. Journal of Management \& Organization, 22(4), 517-534.

Yiu, D. W., Wan, W. P., Ng, F. W., Chen, X., \& Su, J. (2014). Sentimental drivers of social entrepreneurship: A study of China's Guangcai (Glorious) Program. Management and Organization Review, 10(1), 55-80. 